INTERNATIONAL JOURNALOF SYSTEMATIC BACTERIOLOGY

Vol. 19, No. 2 April 1969

pp. $127-137$

Copyright 1969, Iowa State University Press

\title{
MOTILE MARINE BACTERIA II. DNA BASE COMPOSITION
}

Einar Leifson and Manley Mandel

Department of Microbiology, Loyola University (Chicago)

Stritch School of Medicine, Hines, Illinois

and

Department of Biology, The University of Texas

M. D. Anderson Hospital and Tumor Institute at Houston Houston, Texas

ABSTRACT. From a collection of several hundred strains of bacteria from marine sources were selected 57 for determination of DNA base composition. Each strain is classified as to $\mathrm{Na}+\mathrm{requirement,}$ flagellation, somatic shape and aggregation, nature of carbohydrate metabolis $m$, and mol $\%$ GC in the DNA. Other phenotypic characteristics did not show any apparent correlation with the mol \% GC and are not included.

Typical marine bacteria with polar flagella, without somatic aggregation, showed a mol \% GC in the same 40 to 50 range as phenotypically similar terrestrial (non-marine) types of the genus Vibrio, but distinctly lower than the comparable ter restrial types in the genera Aeromonas and Pseudomonas. The mol $\%$ GC of the peritrichous flagellate group of marine origin (few of which were typically marine) was distinctly higher (49-67) than that of the phenotypically similar polar flagellate marine group but only slightly lower, if any, than phenotypically similar terrestrial types such as Agrobacterium spp., Alcaligenes spp., etc.

A general statement may be made that among bacteria of marine origin: 1) the nonaggregating polar flagellate group showed a lower mol $1 \%$ GC than corresponding peritrichous flagellate group; 2) bacteria with the higher $\mathrm{Na}^{+}$ requirement in general showed a lower mol \% 
GC than those with the lower $\mathrm{Na}^{+}$requirement; 3) aggregating bacteria with polar flagella (only types seen) showed a higher mol $\%$ GC than corresponding nonaggregating bacteria; 4) the nature of the carbohydrate metabolism, and a variety of characteristics not recorded, showed little definite correlation with the mol $\%$ GC.

\section{INT RODUCTION}

Aside from the limited data provided by Belser (1964) and those assembled in the compilations of Marmur, Falkow and Mande1 (1963) and Hill (1966), extensive comparative studies of the DNA base compositions of marine bacteria and terrestrial bacteria have not been made. From a collection of several hundred cultures isolated from various marine sources 57 strains were selected for DNA base analysis along with 2 halophobic strains (DW 102 and DW 286) from distilled water for comparative purposes. On the basis of minimal $\mathrm{Na}^{+}$requirement for fairly prompt growth compared to control and no adjustment of osmotic pressure, but other ions at optimal concentration the organisms were classified into 3 general groups:

1) Marine, with a minimal $\mathrm{Na}^{+}$requirement of about 0.1 $\mathrm{M} \mathrm{NaCl}$ or higher;

2) Semimarine, with a minimal $\mathrm{Na}^{+}$requirement of 0.001 to $0.01 \mathrm{M} \mathrm{NaCl}$; and

3) Terrestrial, with a minimal $\mathrm{Na}+$ requirement too low to be determined with the method employed.

The distinction between the semimarine group and the other two groups is not invariably clear-cut and perhaps somewhat arbitrary. If the salts of the marine medium, as detailed under Materials and Methods, are diluted 1:10 with distilled water and added to a nutrient base of $0.2 \%$ peptone and $0.1 \%$ yeast extract the typical bacteria of the marine group fail to show any, or only slight growth on prolonged incubation, while the semimarine and terrestrial types grow quite well. The semimarine and the terrestrial groups are differentiated by the use of a relatively $\mathrm{Na}^{+}$-free medium (v.i.) in which the semimarines fail to grow while the terrestrials grow very well.

A more detailed presentation of the morphological and physiological characteristics of the marine bacteria in the 
collections of the senior author, on which the present study is based, is presented in the paper by Leifson et al. (1964).

\section{MATERIALS AND METHODS}

The cultures for DNA analysis were grown on agar slants of the following composition: Casitone (Difco) $2 \mathrm{gms}$, yeast extract $1 \mathrm{gm}$, agar $1.5 \mathrm{gm}, \mathrm{NaCl} 23 \mathrm{gm}, \mathrm{KCl} 1 \mathrm{gm}, \mathrm{MgCl}_{2} \cdot$ $6 \mathrm{H}_{2} \mathrm{O} 4 \mathrm{gm}, \mathrm{CaCl}_{2} \cdot 2 \mathrm{H}_{2} \mathrm{O} 0.5 \mathrm{gm}$, distilled water $1000 \mathrm{ml}$, $\mathrm{pH}$ 7.5. The cultures were incubated at $20^{\circ} \mathrm{C}$ for 2 or more days until good growth was obtained. The cells were harvested from the surfaces of the slants with a small amount of $15 \mathrm{M} \mathrm{NaCl}$ containing . 1 $\mathrm{M}$ sodium ethylenediaminetetracetate at $\mathrm{pH} 8.0$ (Saline-EDTA) sedimented by centrifugation and resuspended in $1.0 \mathrm{ml}$ of the same solution. Cells were lysed at room temperature by the addition of one-tenth volume of $25 \%(\mathrm{w} / \mathrm{v})$ sodium dodecyl sulfate. The solution was deproteinized by shaking with an equal volume of saline EDTA-saturated phenol adjusted to $\mathrm{pH} 8.0$, and a drop of chloroform. The aqueous phase was separated after centrifugation at $8000 \times \mathrm{G}$ for $10 \mathrm{~min}$. at $5^{\circ} \mathrm{C}$ and the DNA precipitated with 2 volumes of $95 \%$ ethanol. The impure DNA was dissolved in $0.15 \mathrm{M} \mathrm{NaCl}$ containing $0.015 \mathrm{M}$ sodium citrate, $\mathrm{pH} 7.0$.

DNA base composition was estimated from the buoyant density in $\mathrm{CeCl}$ according to Schildkraut, Marmur and Doty (1962) using reference DNA of bacteriophage SP8 (1.742 $\mathrm{g} / \mathrm{cm}^{3}$ ). All samples were determined at least twice and the GC content estimated from the mean values of buoyant density.

Only data which appeared to have significance as regards DNA base composition are included. The minimal $\mathrm{Na}+\mathrm{re}^{-}$ quirement was determined as follows: A solution of $2 \%$ Casitone (Difco) and $1 \%$ yeast extract was passed through an anion-cation demineralizing resin(Deeminizer). To the demineralized peptone-yeast extract solution was added Lalanine, L-glutamic acid, DL-aspartic acid and tris buffer in $0.5 \%$ concentration. The reaction was adjusted with $\mathrm{KOH}$ to $\mathrm{pH}$ 7.5. For determination of the $\mathrm{Na}^{+}$requirement the above base was diluted with distilled water and to it was added $\mathrm{KCl} 0.01 \mathrm{M}, \mathrm{MgSO}_{4} \cdot 7 \mathrm{H}_{2} \mathrm{O} 0.02 \mathrm{M}, \mathrm{CaCl}_{2} \cdot 2 \mathrm{H}_{2} \mathrm{O} 0.005$ $\mathrm{M}$ and $\mathrm{NaCl}$ in increasing concentrations from 0 to $4 \mathrm{M}$. After autoclave sterilization one drop of stock culture was added to a tube of the $\mathrm{NaCl}$ free medium and then one drop of the latter to each of the tubes with the various $\mathrm{NaCl}$ con- 
centrations. The inoculated tubes were incubated at $20^{\circ} \mathrm{C}$ for up to 7 days and a one loop serial transfer made from each tube showing growth.

Flagella strains were by the method of Leifson (1951). The nature of the carbohydrate metabolism was determined using the MOF medium of Leifson (1963).

\section{EXPERIMENTA L DATA}

The experimental data are presented in Table I. The most typical or common polar flagellate marine bacteria have DNA containing 40 to $50 \mathrm{~mol} \% \mathrm{GC}$. The lophotrichous fer mentative marine group showed a narrow range of $39-41.5 \%$ GC. In this group are included the common luminescent marine bacteria. Achromobacter fischeri has a GC mol \% of 40.5 (Belser 1964). Vibrio marinus with a GC mol \% of 40-42 also belongs to this group (Colwell and Mandel 1964). The terrestrial species most closely resembling this group is Aeromonas shigelloides which has a GC mol \% of 52 (Mandel and Rownd 1964). Strain XT9, although with similar GC content is quite different from the others, being semimarine and yellow-brown pigmented. The terrestrial type 8-2, with a GC mol \% of 59 is phenotypically comparable to terrestrial types such as Comamonas terrigena with a GC mol \% of 64 (Leifson and Mandel 1966).

The polar monotrichous fermentative marine group showed a GC mol\% of 40-46.5. Bacteria of this type apparently constitute the major part of the intestinal flora of marine coldblooded animals such as fish and shellfish. Several strains of this group showed a slight but definite somatic curvature. Such curvature does not appear to have much, if any, taxonomic significance. In this group are also included quite a number of strains which showed mixed polar-peritrichous flagellation, particularly when cultured on solid media, and "swarming" colonies on agar plates. Typical of this latter group are strains $\mathrm{XC1}, \mathrm{XD1}$ and $\mathrm{T} 67 \mathrm{C}$ with GC \% of 44, 45.5, and 45.5 respectively. Apparently the formation of lateral flagella, in addition to the polar flagellum, is not associated with a significant change of GC mol \%. The one terrestrial type in this group showed a GC mol \% of 61 . The named terrestrial species with comparable characteristics to the group are Aeromonas hydrophila with a reported GC mol \% of 54 (Mandel and Rownd 1964) and Vibrio comma with a reported GC mol\% of 43-47 (Marmur and Doty 1962). If an established terrestrial genus is chosen for this group of marine bacteria, 
Table I

DNA Base Composition and Selected Properties of Marine, Semimarine and a Few

Terrestrial Types of Bacteria Isolated from Marine Sources

\begin{tabular}{|c|c|c|c|c|c|c|c|}
\hline $\begin{array}{l}\text { Strain } \\
\text { No. }\end{array}$ & $\begin{array}{l}\mathrm{Na}^{+} \\
\text {Requirement }\end{array}$ & Flagellation & $\begin{array}{l}\text { Somatic } \\
\text { shape }\end{array}$ & Aggregation & $\begin{array}{l}\text { Glucose } \\
\text { metabo1ism }\end{array}$ & $\begin{array}{l}\mathrm{GC} \\
\mathrm{mol} \%\end{array}$ & $\begin{array}{l}\text { Comp. } \\
\text { terrestrial species }\end{array}$ \\
\hline $\mathrm{XG} 3$ & marine & 1ophotrichous & straight & none & fermentative & 39.0 & \multirow{6}{*}{$\frac{\text { Aeromonas shigelloides }}{\text { GC } \%=52}$} \\
\hline XP14 & " & " & " & $"$ & " & 40.5 & \\
\hline YBC11 & $"$ & $"$ & $"$ & $"$ & $"$ & 41.0 & \\
\hline $\mathrm{xv} 8$ & $"$ & $"$ & $"$ & $"$ & $"$ & 41.5 & \\
\hline XI8 & $"$ & $"$ & $"$ & $"$ & $"$ & 41.5 & \\
\hline XT 9 & semimarine & $"$ & " & $"$ & $"$ & 40.8 & \\
\hline $8-2$ & terrestrial & 1ophotrichous & straight & none & none & 59.0 & $\frac{\text { Comamonas }}{\mathrm{GC} \%=64}$ terrigena \\
\hline $\mathrm{XF} 1$ & marine & monotrichous & straight & none & fermentative & 40.0 & \multirow{9}{*}{$\begin{array}{l}\frac{\text { Aeromonas hydrophila }}{\text { GC } \%=54} \\
\text { Vibrio } \\
\text { GC } \%=\frac{\text { comma }}{43-47}\end{array}$} \\
\hline Y17 & " & & & $"$ & & 40.0 & \\
\hline XG4 & $"$ & $"$ & " & $"$ & $"$ & 41.0 & \\
\hline $3-5$ & " & $"$ & $"$ & " & $"$ & 42.0 & \\
\hline $\mathrm{XAl}$ & $"$ & $"$ & curved & " & $"$ & 43.5 & \\
\hline $\mathrm{xCl}$ & $"$ & $"$ & straight & $"$ & $"$ & 44.0 & \\
\hline T67c & " & $"$ & $"$ & " & $"$ & 45.5 & \\
\hline XD1 & $"$ & " & " & $"$ & $"$ & 45.5 & \\
\hline $1 \mathrm{C} 2$ & $"$ & $"$ & curved & $"$ & $"$ & 46.5 & \\
\hline$x q^{21}$ & terrestrial & monotrichous & straight & none & fermentative & 61.0 & \\
\hline $\mathrm{XR} 4$ & marine & monotrichous & straight & none & oxidative & 40.5 & \\
\hline XP3 & $"$ & $"$ & " & $"$ & " & 41.0 & \\
\hline $2 \mathrm{I} 2$ & $"$ & " & $"$ & $"$ & $"$ & 41.8 & \\
\hline $\mathrm{XB} 2$ & " & " & $"$ & $"$ & " & 42.0 & Pseudomonas aerug Inosa \\
\hline XI. 3 & $"$ & " & $"$ & $"$ & $"$ & 42.5 & $\overline{\text { GC } \%=67}$ \\
\hline
\end{tabular}


Table I - continued

\begin{tabular}{|c|c|c|c|c|c|c|c|}
\hline $\begin{array}{l}\text { Strain } \\
\text { No. }\end{array}$ & $\begin{array}{l}\mathrm{Na}^{+} \\
\text {Requirement }\end{array}$ & Flagellation & $\begin{array}{l}\text { Somatic } \\
\text { shape }\end{array}$ & Aggregation & $\begin{array}{l}\text { Glucose } \\
\text { metabolism }\end{array}$ & $\begin{array}{l}\mathrm{GC} \\
\mathrm{mol} \%\end{array}$ & $\begin{array}{l}\text { Comp. } \\
\text { terrestrial species }\end{array}$ \\
\hline $\begin{array}{l}x 013 \\
13-11\end{array}$ & $\underset{\|}{\operatorname{marine}}$ & monotrichous & straight & none & $\begin{array}{l}\text { oxidative } \\
" \text { " }\end{array}$ & $\begin{array}{l}42.5 \\
43.0\end{array}$ & \\
\hline XD4 & $"$ & " & " & $"$ & $"$ & 45.5 & \\
\hline $2 \mathrm{BI}$ & $"$ & $"$ & $"$ & $"$ & $"$ & 46.0 & \\
\hline $\mathrm{XI} 1$ & $"$ & $"$ & $"$ & $"$ & $"$ & 46.5 & \\
\hline $2 \mathrm{~N} 6$ & $"$ & $"$ & $"$ & t & $"$ & 46.5 & \\
\hline $\mathrm{xH} 2$ & " & $"$ & " & $"$ & $"$ & 48.0 & \\
\hline $\mathrm{XW1}$ & $"$ & $"$ & curved & $"$ & $"$ & 48.5 & \\
\hline $\begin{array}{l}17 \mathrm{~L} 3 \\
14-2\end{array}$ & $\begin{array}{l}\text { " (weak) } \\
\text { semimarine }\end{array}$ & $\begin{array}{l}\text { mono.-1opho. } \\
\text { monotrichous }\end{array}$ & $\begin{array}{c}\text { curved -spiral } \\
\text { straight }\end{array}$ & $\begin{array}{l}\text { none } \\
\text { " }\end{array}$ & $\begin{array}{c}\text { none } \\
\text { " }\end{array}$ & $\begin{array}{l}51.5 \\
52.0\end{array}$ & \\
\hline 1R5 & " & & curved & $"$ & oxidative & 54.6 & Pseudomonas spp. \\
\hline $5 \mathrm{~L}, 2$ & $"$ & mono.-lopho. & curved-spiral & $"$ & none & 54.8 & Comamonas $\mathrm{sp}$. \\
\hline $1 \mathrm{~s} 5$ & $"$ & monotrichous & curved & $"$ & oxidative & 58.2 & $\overline{\mathrm{GC} \%}=59-70$ \\
\hline $2 \mathrm{~K} 10$ & $"$ & " & $"$ & $"$ & none & 56.5 & \\
\hline $1 \mathrm{R} 4$ & $"$ & $"$ & straight & $"$ & $"$ & 60.0 & \\
\hline XW14 & marine & peritrichous & straight & none & fermentative & 52.0 & $\frac{\text { Salmonella }}{\mathrm{GC} \%=50-53}$ \\
\hline $14-7$ & marine & peritrichous & straight & none & none & 49.0 & \\
\hline $3 \mathrm{~A} 5$ & & " & & & oxidative & 54.0 & Agrobacterium spp. \\
\hline $2 \mathrm{M} 4$ & semimarine & $"$ & " & $"$ & $"$ & 57.0 & GC $\%=59-65$ \\
\hline $11-8$ & marine & $"$ & $"$ & $"$ & $"$ & 57.1 & Alcaligenes spp. \\
\hline$\pi 7$ & " & $"$ & $"$ & $"$ & none & 57.7 & $\mathrm{GC} \%=55-70$ \\
\hline $3 \mathrm{~F}^{2}$ & terrestrial & $"$ & $"$ & $"$ & oxidative & 60.7 & Rhizobium Spp. \\
\hline $1 \mathrm{G} 11$ & marine & $"$ & $"$ & $"$ & " & 61.2 & GC $\%=59-65$ \\
\hline $4-5$ & semimarine & $"$ & " & $"$ & " & 62.8 & \\
\hline $2 \mathrm{~N} 1$ & " & $"$ & $"$ & 1 & $"$ & 63.0 & \\
\hline $12-1$ & terrestrial & $"$ & $"$ & $"$ & none & 64.8 & \\
\hline $9-13$ & semimarine & $"$ & $"$ & $"$ & none & 67.0 & \\
\hline
\end{tabular}


Table I - continued

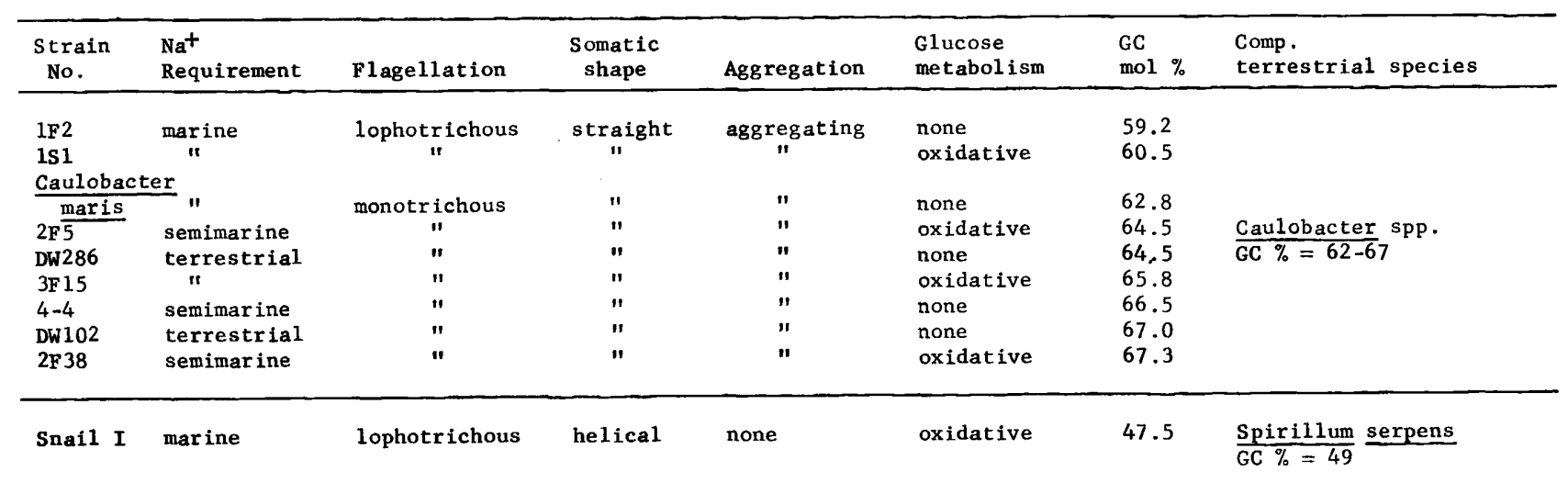


the genus Vibrio is obviously preferable to the genus Aeromonas.

The polar monotrichous oxidative marine group showed a GC mol \% of 40.5-48.5. Bacteria of this type appear to be the most common of the free living marine bacteria. In this group are also found occasional strains with a curved soma and some which produce lateral flagella on solid media, none of which "swarm" however. The average GC mol \% of this group is not significantly different from the average GC mol $\%$ of the corresponding fermentative group. A typical terrestrial species of comparable characteristics is Pseudomonas aeruginosa with a GC mol \% of 67 (Mandel 19 $\overline{66 \text { ). To }}$ place this group of bacteria in the genus Pseudomonas does not seem appropriate, as has been remarked for P. atlantica with 43.5\% GC (Mandel 1966) and P. piscicida with $\overline{44.5 \mathrm{~mol}}$ $\%$ GC (Mandel, Weeks and Colwel1 1965).

In the marine environment, perhaps most frequently near a shore line, are occasionally found free living polar monotrichous flagellate nonfermentative bacteria which are semimarine or even terrestrial in their $\mathrm{Na}^{+}$requirement. Many of these have a vibrio shaped soma and a single polar flagellum in the short forms but a helical som and lophotrichous flagella in the long forms as exemplified by strain $17 \mathrm{~L} 3$. The GC mol \% (52-60) of this semimarine group is distinctly higher than that of the corresponding more typical marine group (40.5-48.5); but also distinctly lower than corresponding typical terrestrial groups such as Pseudomonas and Comamonas with GC mol \% in the 60-70 region. Classification of the curved types of this group in the genus Vibrio would seem ill-advised.

Peritrichous flagellate, fermentative, marine types of bacteria apparently are rare and we present only one strain, $\mathrm{XW14}$, with a GC mol \% of 52 . The organism was very pleomorphic but otherwise is comparable to a Salmonella spp. Salmonella spp. are listed as having a GC mol \% of 50-53 (Marmur and Doty 1962; Schildkraut et al. 1962; Mandel and Rownd 1964). In this case the high $\mathrm{Na}^{-}+\bar{r}$ equirement was not associated with a correspondingly low GC mol \%.

Gram-negative nonfermentative marine bacteria with peritrichous flagella are rare relative to the polar flagellate types. More frequently than not an individual has only a single flagelium located polarly, subpolarly or laterally. Originally many of the cultures were recorded as subpolar monotrichous or lateral monotrichous. The occasional occurrence of individuals with 2-3 peritrichous flagella led to 
the decision to label these types as peritrichous. The GC mol \%, ranging from 49-61, seems to justify this decision. Many of these peritrichous types turned out to be semimarine or actually terrestrial as regarding $\mathrm{Na}^{+}$requirement. The terrestrial genera with corresponding morphology and glucose metabolism are Agrobacterium (GC mol \% 59-65), Rhizobium (GC mol \% 59-65), Achromobacter and Alcaligenes (GC mol \% 55-70). The marine types would appear to have a somewhat lower GC mol \% than the semimarine and terrestrial types.

The bacteria which form distinct somatic aggregations show several morphological as well as physiological differences. Included in Table I are four typical Caulobacter spp. namely Caulobacter maris which is strictly a marine type; 4-4 and 2 F38 which are semimarine and $3 F 15$ which is terrestrial. The difference in GC mol \% in this group between marine, semimarine and terrestrial is not very impressive but it is in the expected direction. Strains $1 F 2$ and $1 S 1$ are typically marine, lophotrichous aggregating types. The GC mol \% of 59.2 and 60.5 respectively are the lowest of the aggregating group. Strain $2 \mathrm{~F} 5$ is semimarine, aggregating, with polar monotrichous flagella of somewhat different appearance from typical Caulobacter spp. Strains DW 102 and DW 286 are aggregating types, distinctly different from typical Caulobacter spp., isolated from distilled water, and very halophobic. According to the literature the GC $\mathrm{mol} \%$ of Caulobacter spp. range from 62 to 67 , but the related Asticcacaulis excentricus has 55. mol \% GC (Poindexter 1964).

\section{TAXONOMIC CONCLUSIONS}

The typical polar flagellate marine bacteria, both fermentative and oxidative in their glucose metabolism, show a GC mol \% between 40 and 50 , which is distinctly lower than that of comparable terrestrial species except Vibrio spp. If an established terrestrial genus is chosen for the fermentative group the genus Vibrio is more suitable than the genus Aeromonas. For the oxidative group the genus Pseudomonas does not appear suitable. The semimarine and terrestrial polar flagellate types of marine origin can well be classified with similar bacteria of terrestrial origin.

Peritrichous flagellate, Gram-negative bacteria appear to be uncommon in the marine environment. They usually show oxidative or no obvious metabolism of glucose. Rela- 
tively few of the cultures studied were typically marine in their $\mathrm{Na}^{+}$requirement but more often semimarine or actually terrestrial. The GC mol \% differs little from comparable terrestrial species and one may speculate that these types have a fairly recent terrestrial origin.

The GC mol \% of the aggregating bacteria with the characteristic morphology of Caulobacter vibrioides was not sufficiently different to justify classification of the marine, semimarine and terrestrial groups into different genera. A separate genus for the lophotrichous types may be justified.

\section{ACKNOW LEDGMENT}

The authors are indebted to Mr. Ronald Stanke for determining the mol \% GC of cultures $5 \mathrm{~L} 2$ and $2 \mathrm{Kl} 0$.

\section{REFERENCES}

Belser, W. L. 1964. DNA base composition as an index to evolutionary affinities in marine bacteria. Evolution 18: 177-182.

Colwell, R. R. and M. Mandel. 1964. Base composition of deoxyribonucleic acid of marine and nonmarine vibrios deduced from buoyant-density measurements in cesium chloride. J. Bacteriol. 88:1816-1817.

Leifson, E. 1951. Staining, shape and arrangement of bacterial flagella. J. Bacteriol. 62:377-389.

- 1963. Determination of carbohydrate metabolism of marine bacteria. J. Bacteriol. 85:1183-1184.

, B. J. Cosenza, R. Murchelano and R. C. Cleverdon. 1964. Motile marine bacteria. I. Techniques, ecology, and general characteristics. J. Bacteriol. 87:652-666. and M. Mandel. 1966. The DNA base composition of a flagellar mutant of Comamonas terrigena ATCC 8461 . Ant. v. Leeuwenhoek 32:57-59.

Mandel, M. 1966. Deoxyribonucleic acid base composition in the genus Pseudomonas. J. gen. Microbiol. 43:273292.

and R. Rownd. 1964. Deoxyribonucleic acid base composition in the Enterobacteriaceae: an evolutionary sequence? In: Taxonomic Biochemistry and Serology (C.A. Leone, Ed.) pp. 585-597. The Ronald Press Co., New York.

, O.B. Weeks and R.R. Colwell. 1965. Deoxyribonucleic acid base composition of Pseudomonas piscicida. J. Bacteriol. 90:1492-1493. 
Marmur, J. and D. Doty. 1962. Determination of the base composition of deoxyribonucleic acid from its thermal denaturation temperature. J. Mol. Biol. 5:109-118.

Poindexter, J.S. 1964. Biological properties and classification of the Caulobacter group. Bacteriol. Revs, 28: 231-295.

Schildkraut, C. L., J. Marmur and P. Doty. 1962. Determination of the base composition of deoxyribonucleic acid from its buoyant density in CeC1. J. Mol. Biol. 4:430444. 